\title{
Protective effects of extracts from the aerial parts of hydroponically cultured ginseng on alcohol-induced liver damage in mice and quantitative analysis of major ginsenosides
}

\author{
Mi Kyoung Lee ${ }^{1} \cdot$ In-Bae Jang² $\cdot$ Min Ho Lee ${ }^{1,3} \cdot$ Dae Young Lee $^{2}$ (D)

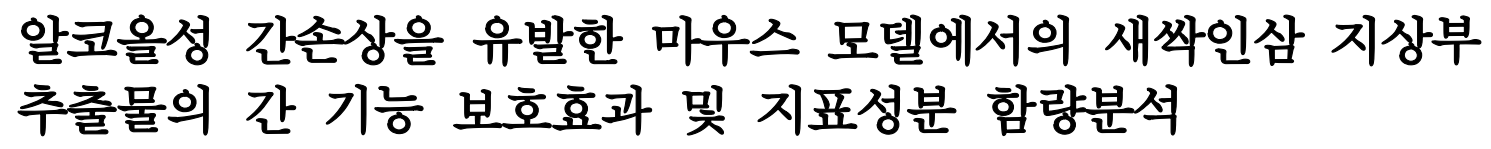

이미경 ${ }^{1}$ - 장인배 ${ }^{2}$ - 이민호 1,3 . 이대영

Received: 30 September 2020 / Accepted: 8 November 2020 / Published Online: 31 December 2020

(C) The Korean Society for Applied Biological Chemistry 2020

\begin{abstract}
We studied the effects of the extract of aerial parts of hydroponically cultured ginseng (HGE) on alcohol-induced liver damage (AILD) in mice. AILD was induced by the oral administration of ethanol (EtOH) $(25 \% ; 5 \mathrm{~g} / \mathrm{kg}$ body weight) for seven days in the study as well as EtOH-only groups. However, HGE (4 and $12 \mathrm{mg} / \mathrm{kg}$ ) was orally administered (once daily for ten consecutive days) only to the study group, three days prior to the EtOH treatment. The HGE-treated group showed significantly lower levels of alanine aminotransferase and aspartate aminotransferase than the EtOH-only group. In addition, HGE administration decreased the level of serum lactate dehydrogenase, a known marker of liver damage. The effect of HGE on AILD was found to be dose dependent, and the consecutive
\end{abstract}

Min Ho Lee $(\bowtie)$

E-mail:minho@eulji.ac.kr

Dae Young Lee $(\bowtie)$

E-mail: dylee0809@gmail.com

${ }^{1}$ Eulji Medical Food Enterprise Eulji, Seongnam 13135, Republic of Korea

${ }^{2}$ Department of Herbal Crop Research, National Institute of Horticultural and Herbal Science, RDA, Eumseong 27709, Republic of Korea

${ }^{3}$ Department of Food Technology and Services, Eulji University, Seongnam 13135, Republic of Korea

This is an Open Access article distributed under the terms of the Creative Commons Attribution Non-Commercial License (http://creativecommons. org/licenses/by-nc/3.0/) which permits unrestricted non-commercial use, distribution, and reproduction in any medium, provided the original work is properly cited. administration of HGE showed no side effects in mice. Our study indicates that HGE treatment can potentially reduce oxidative stress and toxicity in the liver of alcohol-treated mice and that HGE can be a useful therapeutic agent for alcohol-induced hepatotoxicity. Additionally, a simple and efficient high-performance liquid chromatography-ultraviolet detection method was developed for determining the contents of four major ginsenosides in HGE. The aerial parts of hydroponically cultured ginseng were extracted using $70 \%$ fermented ethanol, and the contents of ginsenosides F5, F3, F1, and F2 in HGE were found to be 2.5, 4.4, 1.4, and 23.3 $\mathrm{mg} / \mathrm{g}$, respectively.

Keywords Alcohol-induced liver damage $\cdot$ Ginsenoside · Hepatotoxicity - Hydroponic ginseng - Oxidative stress · Quantitative analysis

\section{서 론}

알코올이 체내로 들어오면 알코올 탈수소효소에 의해 간에서 산 화되어 아세트알데히드가 되고 알데히드 탈수소효소에 의해 acetic acid로 산화되며 일부는 뇨와 이산화탄소로 배출된다[1]. 간에서의 알코올 대사과정은 CYP2E1, aldehyde oxidase등을 유 도해서 생체 내 reactive oxygen species (ROS)를 생성시켜 산 화 스트레스를 일으킨다[2]. 이러한 산화스트레스는 면역반응을 일으키거나 간 세포내 염증반응을 일으켜 간 손상을 유발하며 항산화 방어체계의 균형이 깨지면 각종 질환이 생기게 된다[3]. 
알코올 섭취에 따른 간 손상(alcohol-induced liver damage, $\mathrm{AILD})$ 은 간과 관련된 질병과 사망의 가장 공통적인 원인으로 인식되고 있다[4]. $\mathrm{AILD}$ 는 그 원인이 잘 알려져 있지만, 알코 올이 $\mathrm{AILD}$ 를 유발하는 메커니즘은 완벽하게 알려져 있지 않다. 많은 요소들이 AILD의 유발과 진행에 관련되어 있는데, 성별, 인종, 영양 상태, 생체 에너지 기능 장애, 면역기작, 산화 스트 레스 등이 그 원인이다[5]. 에탄올에 의한 독성은 고지혈증, 지 방간 및 간경변과 같은 간 기능의 이상을 유발하고, 만성적 간 조직의 구조 및 기능에 치명적인 손상을 가져오게 된다. 만성 적인 알코올의 섭취는 지방산의 산화를 저해함으로써 혈중 중 성지방의 농도를 높일 수 있고 결과적으로 지방간의 원인이 될 수 있다[6]. 또한 methionine의 대사 이상을 초래함으로써 강력 한 항산화 작용을 나타내는 glutathione의 생산을 억제하게 된 다[7]. 척추동물에서는 이러한 산화적 손상을 대비해서 superoxide dismutase (SOD), glutathione peroxidase, catalase 등의 항산화 효소를 분비하도록 체계화되어 있지만[8] 손상을 완벽하게 방지하기에는 충분하지 못하다[9]. 이러한 산화적 스 트레스가 숙주동물의 항산화 역량을 넘어서게 되면 간 손상, 간 세포의 자멸사 혹은 괴사를 유발하게 된다[10]. 간은 소화된 알 코올에 대한 주요 대사 기관이기 때문에, 간이 알코올에 노출 되었을 때 일어나는 일련의 생리적인 현상들이 간에 해를 입히 게 될 수도 있다. 그래서 간과 혈청에서의 생화학적 마커(인자) 들은 간 질환의 초기 진단에 효과적인 방법으로써 널리 사용되 고 있고, 간 병변이나 급성 알코올 질환의 예방과 치료를 위한 기능적인 요소들을 결정하는데 사용되고 있다[11].

인삼(Panax ginseng)은 두릅나무과에 속하는 다년생 초본 식 물로, 예로부터 뿌리를 식용함으로써 건강 보조제 또는 강장제 로 사용되어왔다. 인삼의 주요한 사포닌 성분인 진세노사이드 (Ginsenoside)의 효능은 다양하게 보고되어 있다[12,13]. 보고된 효능으로는 항염증[14], 간 섬유화[15], 항암[16], 항당뇨[17], 항 산화18], 기억력 개선[19], 골다공증[17] 등이 있다. 최근 수경 재배 시설을 이용한 새싹인삼 재배의 관심이 높아지고 있는데 [13], 이러한 방법은 연작장애가 없고, 단위면적당 생산성이 높 으며, 병해충 예방 및 생육기간이 단축된다는 장점을 가진다. 인삼은 예로부터 뿌리를 한약재 혹은 보양식품으로 사용하고 있 으나, 새싹인삼은 뿌리와 함께 잎의 이용성이 높다는 점에서 관 심을 받고 있다. 인삼의 잎은 뿌리와 비교하면 진세노사이드의 종류와 함량이 다르지만, 총 진세노사이드의 함량은 뿌리보다 높다고 보고되어 있다[20]. 이러한 장점은 기존의 인삼을 건강 기능식품이나 한약재로 이용하는 방법 외에 밥상 위의 신선한 기능성 채소로서 식용할 수 있음을 시사한다. 최근에는 새싹인 삼의 성장과 진세노사이드에 영향을 미치는 광량이나 물의 미 네랄 함량 등의 재배 연구는 활발하지만[16], 기능성에 관한 연 구는 미비한 실정이다. 따라서, 본 연구에서는 알코올 섭취 후 에 나타나는 증상에 대하여 예방할 수 있는 천연소재를 찾고자 새싹인삼 지상부 추출물을 이용하여 알코올에 의해 간이 손상 된 동물모델을 이용하여 간 보호 효과를 확인하고자 하였으며, 새싹인삼의 지표성분 후보가 될 수 있는 주요한 성분에 대하여 정량분석을 진행하였다.

\section{재료 및 방법}

\section{실험재료}

본 연구에서 사용된 수경재배 인삼은 국립원예특작과학원 인삼 특작부에서 제공된 것으로, 환경조절이 가능한 식물공장에서 1 년근 묘삼을 식재하여, 30 일간 재배한 새싹인삼을 수확하여 사 용하였다. 표본시료(NIHHS-1801)는 국립원예특작과학원 인삼특 작부 성분분석실에 보관되어 있다.

\section{시약 및 기기}

새싹인삼 지상부 추출물의 성분분석에 사용한 ginsenoside $\mathrm{F} 1$, $\mathrm{F} 2, \mathrm{~F} 3$, 및 F5 성분은 ChromaDex사(Irvine, CA, USA)로부터 구입하여 사용하였다. 정량분석에 사용된 장비는 Agilent 1200 series HPLC system (Agilent, Santa Clara, CA, USA)을 사 용하였다. 분석을 위한 증류수, Methanol $(\mathrm{MeOH})$ 및 Acetonitile 은 HPLC grade (Fisher Scientific Korea Ltd., Seoul, Korea) 를 사용하였으며, 분석 용매에 첨가한 Formic Acid는 $99.0 \%$ 의 Optima $^{\mathrm{TM}}$ LC/MS (Fisher Scientific) 급을 사용하였다. 시료의 항산화 활성 실험을 위해 1,1-diphenyl-2-picryl-hydrazyl (DPPH, Calbiochem, San Diego, USA), 2,2-azino-bis-3-ethylbenzothiazoline6-sulfonicacid (ABTS, Sigma, St. Louis, MO, USA), SOD Assay kit-WST (Sigma) 제품을 사용하였다. 그 외의 시약 및 용매는 모두 일급 이상의 시약을 구입하여 사용하였으며 기기 는 별도 표기하였다.

\section{추출물의 제조}

건조된 새싹인삼 지상부(잎, 줄기)을 잘게 분쇄한 후, 환류추출 장비를 이용하여 $100 \mathrm{~g}$ 의 새싹인삼 지상부 건조물에 $800 \mathrm{~mL}$ 의 $30 \%$ 발효주정을 넣고 $70{ }^{\circ} \mathrm{C}$ 에서 4 시간 동안 열수 추출하였다. 1차 추출 후 Filter paper (No. 1, WHATMAN, Maidstone, England)를 이용하여 추출액을 여과하였고, 감압증류장치 $(\mathrm{N}-1000$, EYELA, Tokyo, Japan)로 농축하였다. 농축된 엑스를 $-80{ }^{\circ} \mathrm{C}$ 초저온 냉동고 및 동결건조기 (FD8508, Ilshin, Dongducheon, Korea)를 이용하여 건조하여 주정 추출물 분말을 얻었다.

\section{HPLC를 이용한 정량분석}

$70 \%$ 발효주정 추출물로 얻어진 새싹인삼 지상부 동결 건조물 을 $100 \mathrm{mg}$ 을 $1 \mathrm{~mL}$ 의 메탄올에 녹이고 $0.2 \mu \mathrm{m}$ 의 $13 \mathrm{~mm}$ 디스 크 필터(Chromdisc Co., Daegu, Korea)로 여과하여 UV 검출 기가 장착된 HPLC로 정량분석 하였다. 사용된 컬럼은 Advanced Materials Technology사의 Halo ${ }^{\circledR}$ RP-Amide $(4.6 \times 150 \mathrm{~mm}, 2.7$ $\mu \mathrm{m}$, Wilmington, DE, USA)를 사용하여 $50^{\circ} \mathrm{C}$ 에서 실시하였다. 이동상은 증류수 $(\mathrm{A})$ 및 acetonitrile $(\mathrm{B})$ 를 상용하였으며, $\mathrm{B}$ 를 6 분 동안 $27^{\circ} \mathrm{C}$ 에서 $28 \%$ 로 증가시킨 후, 4 분 동안 $28 \%$ 로 유지, 다시 20 분 동안 $\mathrm{B}$ 를 $28^{\circ} \mathrm{C}$ 에서 $34 \%$ 로 증가시켰고 이후 3 분 동안 $34{ }^{\circ} \mathrm{C}$ 에서 $80 \%$ 로 증가시켰으며 그 후에 2 분 동안 $\mathrm{B}$ 를 $27 \%$ 수준으로 유지시키는 조건으로 기울기 용리 하였다. 이때 유속은 $0.8 \mathrm{~mL} / \mathrm{min}$ 으로 하고, $\mathrm{UV}$ 검출기의 $203 \mathrm{~nm}$ 파장에서 흡광도를 측정하였다. 정량분석에 4종의 ginsenoside는 $\mathrm{MeOH}$ 
에 용해시켜 표준용액을 제조하였으며, 분석 시 주입된 용량은 $10 \mu \mathrm{L}$ 이며, 정량분석 시 사용된 농도범위, 검량곡선 및 검량선 식은 Table 1에 나태내었다.

\section{DPPH 라디칼 제거 활성}

시료의 항산화 활성은 DPPH 라디칼 제거 활성 방법을 이용하 여 측정하였다[21]. 즉, $0.6 \mathrm{mM} \mathrm{DPPH}$ 용액 $0.1 \mathrm{~mL}$ 에 시료를 동량으로 첨가하고, 실온에서 암상태로 30 분간 반응시킨 후 $517 \mathrm{~nm}$ 에서 흡광도를 측정하였다(infinite m200, TECAN, Männedorf, Switzerland). 결과 값은 시료를 첨가하지 않은 대 조군과 비교하여 라디칼의 제거 활성으로 나타내었다. 실험은 3 회 반복 수행하여 평균값을 제시하였다.

$$
\mathrm{DPPH} \text { 라디칼 제거 활성 }(\%)=(1-\mathrm{A} / \mathrm{B}) \times 100
$$

$$
\mathrm{A} \text { : 시료첨가구의 흡광도, } \mathrm{B} \text { : 대조구의 흡광도 }
$$

\section{$\mathrm{ABTS}+$ 라디칼 제거 활성}

$\mathrm{ABTS}$ 라디칼 제거활성은 Dewanto 등[22]의 방법을 응용하여 측정하였다. ABTS $7.4 \mathrm{mM}$ 과 potassium persulfate $2.7 \mathrm{mM}$ 을 섞어 하루 동안 암소에 방치하여 $\mathrm{ABTS}$ 양이온을 형성시킨 후, 이 용액을 $735 \mathrm{~nm}$ 에서 흡광도 값이 0.8-1.0가 되도록 희석해서 사용하였다. 희석된 $\mathrm{ABTS}$ 용액에 시료를 동량으로 넣고, 5-10 분 반응시킨 후에 $735 \mathrm{~nm}$ 에서 흡광도를 측정하였다. 결과 값은 시료를 첨가하지 않은 대조군과 비교하여 라디칼의 제거활성으 로 나타냈다. 실험은 3 회 반복 수행하여 평균값으로 나타내었다.

\section{$\mathrm{ABTS}$ 라디칼 제거 활성 $(\%)=(1-\mathrm{A} / \mathrm{B}) \times 100$}

\section{SOD 유사 활성 측정}

$\mathrm{SOD}$ 유사 활성 실험은SOD Assay kit-WST를 사용하여 측정하 였다. SOD 유사 활성이 NBT (nitroblue tetrazolium)의 환원 저해 능력을 실험하는 photochemical NBT method를 사용하였 다. 반응액은 $50 \mathrm{mM}$ carbonic buffer $(\mathrm{pH} 10.2), 0.1 \mathrm{mM}$ EDTA, $0.1 \mathrm{mM}$ xanthine, $0.025 \mathrm{mM}$ NBT로 하였고, NBT의 환원 저해율을 $450 \mathrm{~nm}$ 에서 측정하였다. $\mathrm{SOD}$ 효소 유사 활성 은 다음의 계산식에 의해 환산하였다.

$\mathrm{SOD}$ 활성 $(\mathrm{NBT}$ 환원 저해율, $\%)=\{[($ Ablank1-Ablank3) -(Asample-Ablank2)]/(Ablank1-Ablank3) $\} \times 100$

\section{실험동물 및 식이}

본 실험에 사용한 실험동물은 5주령 된 수컷 $\mathrm{Balb} / \mathrm{c}$ 마우스로 라온 바이오로부터 공급받아 1 주일간 일정한 조건(기온 $25 \pm 3{ }^{\circ} \mathrm{C}$, 습도 $50 \%$, 명암주기 12 시간)에 적응시킨 후 실험에 사용하였다. 모든 실험동물의 취급 및 사후 처리는 경희대학교 동물실험 윤 리위원회의 기준(승인번호 KHUASP-18-006)을 준수하여 수행 되었다. 알코올 간독성(AILD, alcohol induced-liver damage)의 유발은 Harrison-Findik 등[23]의 방법에 따라 이루어졌다. 실험 군은 대조군(Con), 알코올 투여군(EtOH), 알코올-새싹인삼 지상 부 추출물 투여군 $(\mathrm{EtOH} / \mathrm{HGE})$ 으로 각 군에 7 마리씩 무작위로 나누었다. 정상군과 알코올 투여군은 PBS (phosphate-bufered saline) 버퍼를, 알코올-새싹인삼 지상부 추출물 투여군은 $\mathrm{HGE}$ 추출물을 각각 4 와 $12 \mathrm{mg} / \mathrm{kg}$ 농도로 10 일간 경구 투여하였다.
모든 실험군은 경구 투여 3일 후부터 대조군은 PBS 버퍼를, 알 코올 투여군과 알코올-HGE 투여군은 $25 \%$ ethanol $(\mathrm{w} / \mathrm{v})$ (Merck, Palo Alto, CA, USA)을 $5 \mathrm{~g} / \mathrm{kg}$ 농도로 7일간 경구 투 여 하였다. 최종 투여 후 24시간 절식 시킨 다음, 혈액과 조직 을 채취하였다.

\section{생화학적 요소 측정(ALT/ AST/ LDH)}

시료의 채취는 2\% isofluorane (Piramal Inc., Phennsylvania, USA)을 이용하여 마취 후 개복하여 heparin (H3393, SigmaAldrich) 처리한 주사기를 대정맥에서 혈액을 채취하였으며 간 (Liver)과 비장(spleen) 또한 적출하였다. 채취한 혈액은 상온에 서 $1,200 \times \mathrm{g}, 20$ 분간 원심분리 후 혈장을 분리하여 분석에 이용 하였으며, 간과 비장 조직은 생리식염수로 수세 후 중량 측정 및 분석에 사용되었다. Aspartate aminotransferase (AST)와 alanine aminotransferase (ALT)의 활성은 ALT와 AST kit (Sigma-Aldrich) 를 사용해서 비색정량으로 계산하였다. 혈장 내 $\mathrm{LDH}$ (lactate dehydrogenase)의 양은 $\mathrm{LDH}$ assay kit (Sigma-Aldrich)로 측정 되었다.

\section{통계처리}

실험결과는 평균값과 표준편차(mean \pm standard)로 표시하였고, 각 시료군 간의 통계적 분석은 본 실험에서 얻은 결과를 student t-test와 Duncan's multiple range test를 이용하여 각 그룹 간 통계적 유의성을 검정하였다. 각 군의 유의성은 $p<0.05$ 수준으 로 검정하였다.

\section{결과 및 고찰}

\section{새싹인삼 지상부 추출물로부터 주요성분 정량분석}

일반적으로 인삼 뿌리에서부터 분리보고 된 인삼 사포닌을 ginsenoside Rx라고 명명하며, "R"은 Radix 또는 뿌리 (Root)를 의미한다[24]. 본연구에서는 인삼 뿌리가 아닌, 새싹인삼 지상부 를 대상으로 실험을 하였기에, 인삼 꽃봉오리 (flower buds)에 서 분리보고가 되어 있는 ginsenoside $\mathrm{F} 1, \mathrm{~F} 2, \mathrm{~F} 3$, 및 F5를 정 량분석 하였다. Ginsenoside 4종의 정량분석을 위해 UV 검출기 가 장착된 $\mathrm{HPLC}$ 를 사용하여 추출된 새싹인삼 지상부를 분석 하였다. 최적의 용매 기울기 조건을 확립하고 분석된 결과의 머 무름 시간을 비교하였을 때, ginsenoside F5 (1)는 18.89분, F3 (2)는 19.60분, F1 (3)는 26.40분, 및 F2 (4)는 35.68분에서 검 출되었다(Fig. 1). 검량 곡선은 표준물질의 5 농도 범위 안에서 측정된 값을 회기 분석을 통해 작성하였다. 상관계수 $\left(r^{2}\right)$ 는 화합 물 4종에 대해 0.9998에서 0.9999로 매우 높은 값을 보여주었 다(Table 1). Ginsenoside 4종을 함량분석한 결과, $2.5 \mathrm{mg} / \mathrm{g}$ (1), $4.4 \mathrm{mg} / \mathrm{g}$ (2), $1.4 \mathrm{mg} / \mathrm{g}$ (3), 및 $23.3 \mathrm{mg} / \mathrm{g} \mathrm{(4)으로} \mathrm{확인되었다.}$

Tung 등[25]으로부터 인삼 추출물과 ginsenoside $\operatorname{Rg} 1$ 등 주요 한 물질이 간기능 개선 효과가 있는 것으로 알려져 있으나, 새 싹인삼 지상부 추출물의 알코올성 간손상을 유발한 마우스 모 델에서의 간 보호 활성 및 인삼 꽃봉오리에서 분리보고가 되어 있는 ginsenoside 4 종의 함량분석은 이번 연구에서 처음 보고하 였다. 
Table 1 Linear regression data and contents of ginsenosides 1-4 [ginsenoside F5 (1), ginsenoside F3 (2), ginsenoside F1 (3) and ginsenoside F2 (4)]

\begin{tabular}{cccccc}
\hline \hline ginsenosides & $\mathrm{Rt}^{\mathrm{a}}(\mathrm{min})$ & Calibration Curve $^{\mathrm{b}}$ & $R^{2 \mathrm{c}}$ & Concentration range $(\mathrm{ng} / \mu \mathrm{L}) \mathrm{Amount} \mathrm{d}^{\mathrm{d}}(\mathrm{mg} / \mathrm{g})$ \\
\hline 1 & 18.89 & $\mathrm{y}=1.542169 \mathrm{x}-0.354869$ & 0.9992 & $10-100$ & 2.5 \\
2 & 19.60 & $\mathrm{y}=1.264090-1.472501$ & 0.9980 & $10-100$ & 4.4 \\
3 & 26.40 & $\mathrm{y}=1.904205 \mathrm{x}+0.632294$ & 0.9999 & $10-100$ & 1.4 \\
4 & 35.68 & $\mathrm{y}=1.3603376 \mathrm{x}+0.347523$ & 0.9999 & $10-100$ & 23.3 \\
\hline
\end{tabular}

${ }^{\mathrm{a}} \mathrm{Rt}$, retention time. ${ }^{\mathrm{b}} y$, logarithmic value of peak area; $x$, logarithmic value of amount injected. ${ }^{\mathrm{c}} \mathrm{R}^{2}$, linearity. ${ }^{\mathrm{d}}$ Mean values of samples $(n=3)$

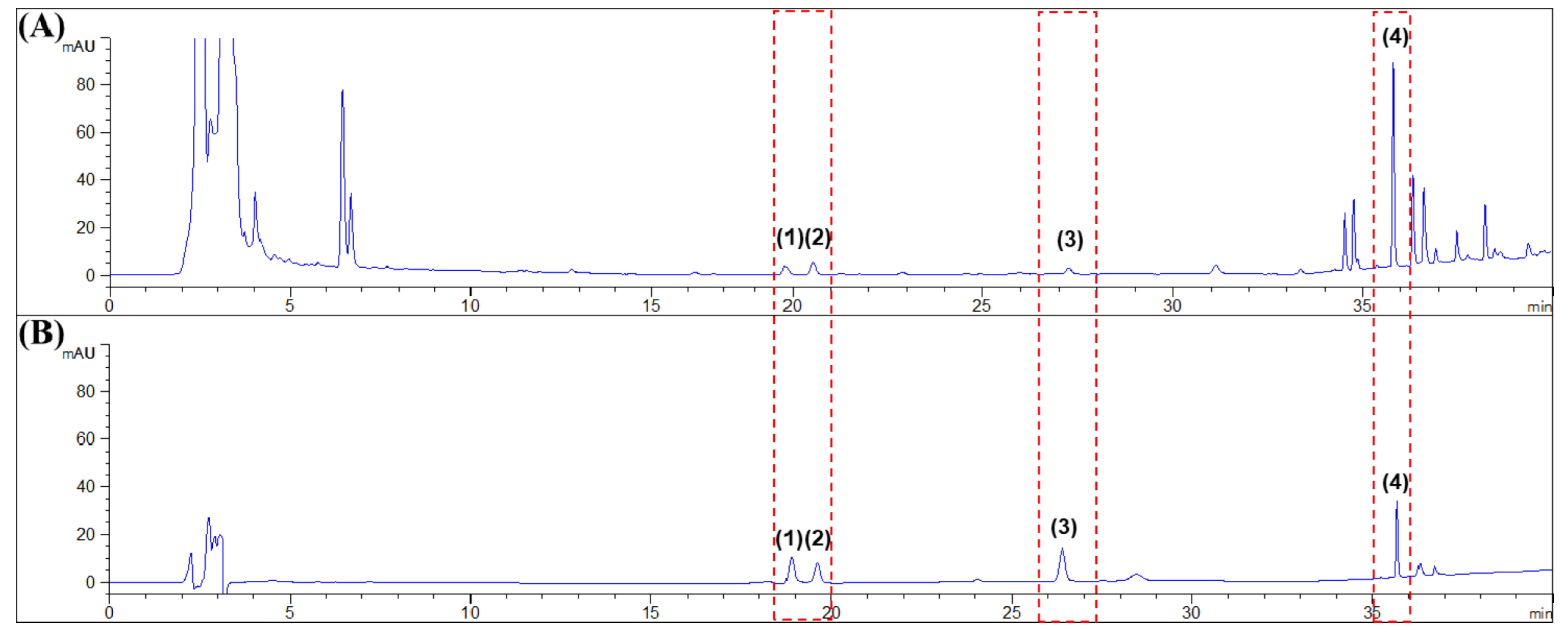

Fig. 1 HPLC analysis of aerial parts of hydroponic ginseng. (A) Chromatogram of extract from the aerial parts of hydroponic ginseng at $203 \mathrm{~nm}$ and (B) Separation of a standard mixture of ginsenosides 1-4 [ginsenoside F5 (1), ginsenoside F3 (2), ginsenoside F1 (3) and ginsenoside F2 (4)]

\section{시료의 항산화 활성}

알코올 섭취에 의한 독성물질 생성의 예방 효과를 확인하기 위 해 시료 자체의 항산화능을 알아보았다. 새싹인삼 지상부 추출 물 (HGE)들의 항산화 활성 분석을 위해 DPPH, ABTS 라디칼 소거 활성과 $\mathrm{SOD}$ (super oxide dismutase)활성을 비교 분석하 여 나타내었다. $\mathrm{DPPH}$ 는 짙은 보라색의 안정한 항산화 물질에 의해 환원 반응이 일어나면서 보라색이 탈색되는 원리를 이용 하여 측정하고, 그 측정 방법이 비교적 간단하여 시료로부터 항 산화 활성을 측정하는데 주로 이용된다 [23]. 새싹인삼 지상부 추출물 $(\mathrm{HGE})$ 의 $\mathrm{DPPH}$ 라디칼 소거능을 측정한 결과(Fig. 2-A), $50,100,250,500,1000(\mu \mathrm{g} / \mathrm{mL})$ 농도에서 $10 \pm 2.3,16.5 \pm 2.8$, $21 \pm 1.4,43 \pm 3.1,65 \pm 3.6 \%$ 로 나타나 농도 의존적으로 라디칼 소 거능이 증가함을 보였다. $\mathrm{ABTS}$ 라디칼 소거 활성을 $\mathrm{DPPH}$ 방 법과 함께 항산화능을 스크리닝 하는데 많이 이용되며 ABTS 를 peroxidase, $\mathrm{H}_{2} \mathrm{O}_{2}$ 와 반응시켜 생성된 활성 양이온인 $\mathrm{ABTS}+$ 가 시료 중의 항산화성 물질에 의해 제거되어 고유의 청록색의 변화를 흡광도 값으로 나타내어 추출물의 $\mathrm{ABTS}+$ 라디칼 소거 활성을 측정할 수 있다 [26]. 새싹인삼 지상부 추출물 (HGE)의 ABTS 양이온 소거활성을 농도별로 조사한 결과를 Fig. 2-B에

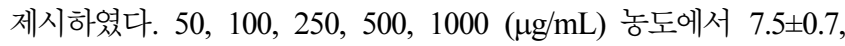
$23 \pm 2.5,40.3 \pm 2.7,60 \pm 4.6,77 \pm 5.2 \%$ 로 나타나 농도 의존적으로 라디칼 소거능이 증가함을 보였다. 특히, $1000 \mu \mathrm{g} / \mathrm{mL}$ 에서 $70 \%$ 이상의 소거활성을 나타내었는데, 인삼, 홍삼 추출물의 항산화 연구에서와 마찬가지로 추출물의 농도가 증가할수록 DPPH 라 디칼 소거능이 증가하였고[27], $\mathrm{HGE}$ 추출물의 경우 더 높은 활
성을 나타내었다. Superoxide는 산소가 전자를 하나 받아 환원 된 형태로, 체내의 산화적 손상을 야기할 수 있으며 이것을 산 소로 전환시키는 것이 $\mathrm{SOD}$ 이다. $\mathrm{SOD}$ 유사 활성이란 $\mathrm{SOD}$ 처 럼 superoxide를 정상의 산소로 전환시킬 수는 없으나, superoxide 의 반응성을 억제하여 생체를 산화적 손상으로부터 보호할 수 있는 phytochemical의 저분자 물질을 일컫는다[28]. 새싹인삼 지 상부 추출물(HGE)의 $\mathrm{SOD}$ 유사 활성을 측정해 본 결과(Fig. $2 \mathrm{C})$, 시료의 농도가 증가할수록 $\mathrm{SOD}$ 유사활성이 증가하였다. $50,100,250,500,1000(\mu \mathrm{g} / \mathrm{mL})$ 농도에서 $5.4 \pm 1.1,13.6 \pm 2.4$, $28 \pm 4.2,42.5 \pm 4.4,48.9 \pm 5.0 \%$ 정도의 활성을 나타내었다. 1000 $\mu \mathrm{g} / \mathrm{mL}$ 농도의 시료의 경우 $\mathrm{DPPH}$ 라디칼 소거활성과 $\mathrm{ABTS}$ 라디칼 소거활성에 비해 $\mathrm{SOD}$ 유사활성의 정도가 $50 \%$ 이하로 다소 낮았는데, 이는 다른 이전의 연구들에서도 유사한 결과들 이 있었다. 새싹인삼 지상부 추출물에서 알코올로 유발된 산화 적 스트레스에 의한 간 손상에 대한 보호 효과를 확인해 보기 위해 새싹인삼 지상부 추출물(HGE)을 $30 \%$ 발효주정(발효 에 탄올)을 사용하여 $70^{\circ} \mathrm{C}$ 에서 4 시간 동안 열수 추출하였다. 기존 에 인삼 추출물을 확보하는 방법은 주로 공업용 에탄올이나 메 탄올[13]과 같은 실험용 용매를 이용한 방법으로 추출 효율을 높이는 방법이 많이 이용되었지만, 본연구에서는 식품에 원료로 사용하기에 적합하고, 짧은 추출시간과 동시에 적당한 추출온도 를 사용하여 추출물의 유효성분의 변화를 최소화하였다. 앞서 언급했듯이, 새싹인삼 지상부 추출물 $(\mathrm{HGE})$ 의 항산화 활성을 확 인해 보기 위해 $\mathrm{DPPH}, \mathrm{ABTS}$, 및 $\mathrm{SOD}$ 유사 활성을 측정 결 과, 농도 의존적으로 항산화 활성이 증가함을 확인하였다. 따라 
(A)

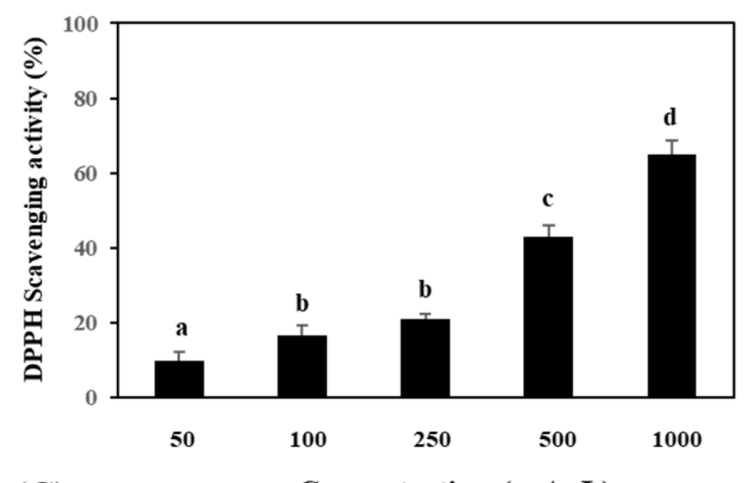

(C)

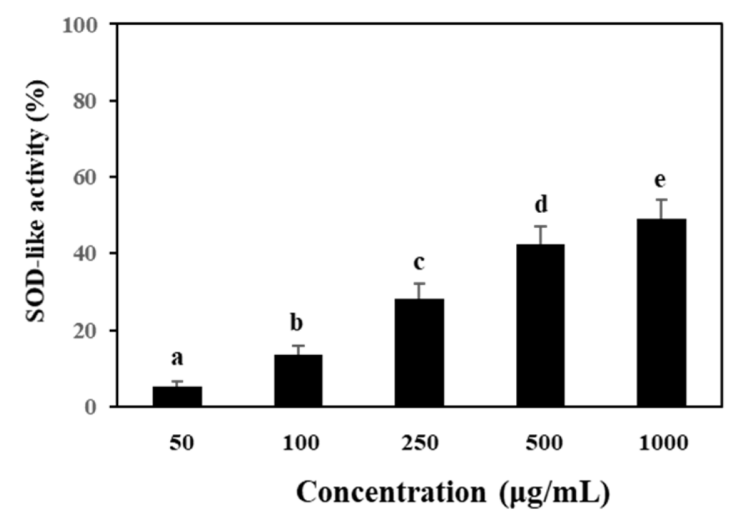

서, 알코올로 간독성을 유발한 동물모델에서의 간 보호 효과를 확인해 보고자 하였다.

\section{체중 및 간 중량 변화}

알코올에 의한 간손상에 대한 증상은 다양하게 나타나지만 대 표적으로 지방간을 들 수 있고, 지방간으로 인해 간의 부피와 중량을 증가시킬 수 있다는 보고들이 있다[29]. 전형적인 간손 상의 특징으로는 알코올이 세포내의 ROS (활성산소)를 증가시 키고 미토콘드리아의 손상과 지질 과산화를 유도하는게 있다. 이 과정에서 형성된 아세트알데히드가 세포 내 물질의 배출을 억제시켜서 세포 내의 단백질, 지질, 수분 등이 간세포를 팽창 시키게 된다[18]. 따라서, 이번 연구에서는 실험동물의 체중 및 간 무게 측정과 체중에 대한 간 중량의 비율 등이 간손상의 정 도를 확인할 수 있는 지표로 사용되었다. 알코올은 간의 기능 이상을 유도하는 물질로 사용되었다. 7 일 동안 $25 \%$ 농도의 에 탄올을 마우스에 경구투여 하였으며, 실험 마지막 날에 체중과 기관(간, 비장) 무게를 측정하였다. $25 \%$ 의 에탄올을 투여한 마 우스는 체중이 감소되었을 뿐 아니라, 간과 비장에서의 무게 감 소도 보였다(Fig. 3). 기관 무게의 감소는 에탄올 처리에 의해 유도된 독성(toxicity) 때문인 듯 하다. 새싹인삼 지상부 추출물 (HGE)을 급여하는 동안 마우스의 비정상적인 체중의 증가와 감 소는 관찰되지 않았다(data not shown). $\mathrm{HGE}$ 의 경구투여는 알 코올로 유발된 간독성 상태에서 마우스의 체중과 비장 무게를 회복시켰고, 체중에 대한 상대적인 간 무게의 경우는 $\mathrm{EtOH}$ 군 이 가장 높은 수치를 나타내어 알코올의 처리가 상대적으로 간 의 중량을 증가시키는 것으로 확인되었다. 이것은 이전에 연구
(B)

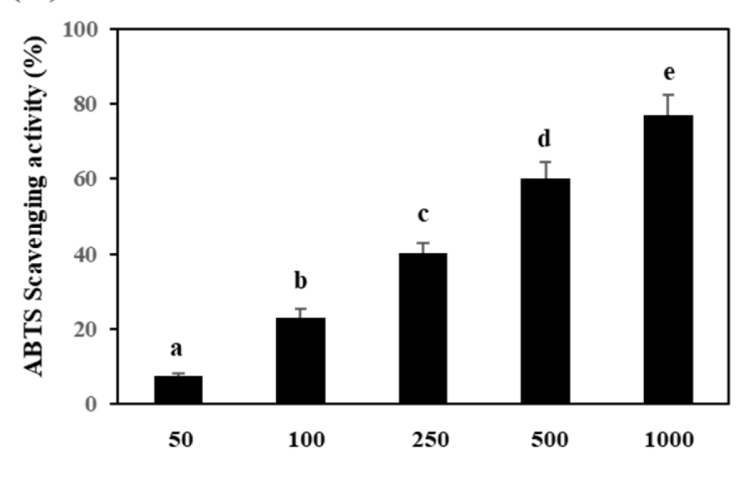

Concentration $(\mu \mathrm{g} / \mathrm{mL})$

Fig. 2 Anti-oxidant activity (\%) of hydroponic Ginseng leaf extract (HGE). (A): DPPH free radical scavenging activity, (B): ABTS free radical scavenging activity, (C): SOD-like sctivity. The results were expressed as mean $\pm \mathrm{SD}$ from three independent experiments. Different small letters (a-e) on the error bar indicate a significant difference $(p<0.05)$

되었던 알코올로 유발한 간독성 동물 모델에서 체중에 비해 상 대적으로 간 중량이 유의적으로 상승되었다고 보고한 연구 결 과 [30]와 일치하였다. 결과적으로, $\mathrm{HGE}$ 의 적용이 간조직 무게 증가에는 효과가 없는 이유가 확실히 밝혀지진 않지만, 아마도 이러한 작용은 영양학적 지원(nutritional support) 혹은 에탄올 에 의한 손상으로부터의 간세포 보호 작용과 연관되어 있는 것 으로 분석되었다.

\section{Alanine aminotransferase와 aspartate aminotransferase 활 성도}

간 조직이 어떠한 독성의 자극에 의해 손상되거나 질병화 되면 손상된 간세포들은 혈관으로 $\mathrm{ALT}$ 와 $\mathrm{AST}$ 를 방출되면서 혈청내 의 효소들의 수치가 증가하게 된다[31]. 특히 알코올로 유발된 급성 간독성을 보이는 간에서의 $\mathrm{ALT}$ 와 $\mathrm{AST}$ 의 활성이 증가된 다고 보고되고 있다[5]. 따라서, 알코올성 간손상을 입은 실험 동물에서의 간 기능 회복에 대한 새싹인삼 지상부 추출물의 효 과를 혈중 ALT 및 AST 활성으로 확인한 결과, 알코올만 처리 한 $\mathrm{EtOH}$ 그룹의 경우 ALT, AST 각각 $145.33 \pm 34.43,218.67$ $\pm 58.29 \mathrm{U} / \mathrm{L}$ 의 수치를 보여 실험군내에서 유의적으로 가장 높은 수치를 나타내었으므로 알코올로 인한 간독성이 유발됨을 확인 하였다 $(p<0.05)$. 반면에 알코올 투여와 $\mathrm{HGE}$ 를 함께 처리한 군 의 ALT 및 AST 수치는 알코올만 단독으로 투여했던 군의 ALT 및 AST 수치에 비해 상당히 낮아졌으며, 무처리 대조군 과 유사한 정도의 수치를 나타낸 경우도 있었다. 특히, ALT 활 성의 경우, $\mathrm{HGE}$ 투여군의 수치는 각각 $78.50 \pm 27.15,58.80 \pm$ $13.07 \mathrm{U} / \mathrm{L}$ 으로 무처리 대조군 $(66.80 \pm 25.07 \mathrm{U} / \mathrm{L})$ 과 비슷한 수치 
(A) Body

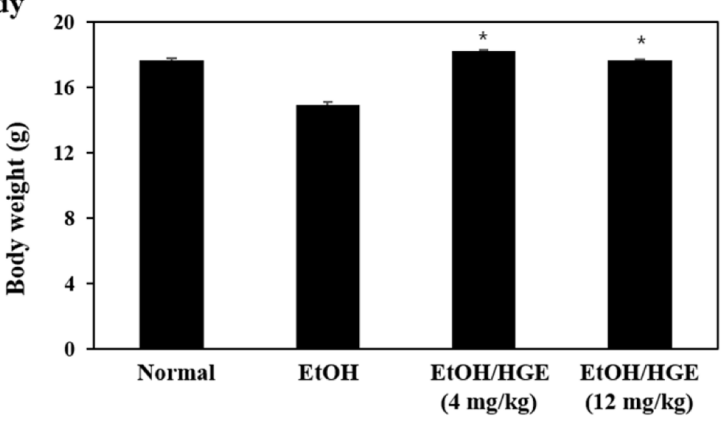

(C) Spleen

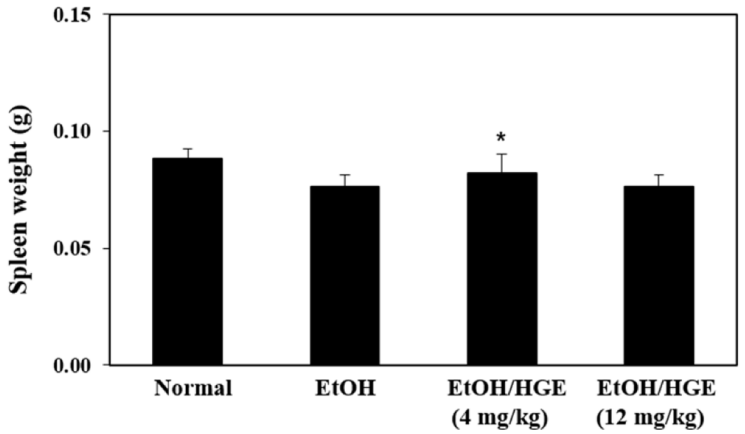

(B) Liver

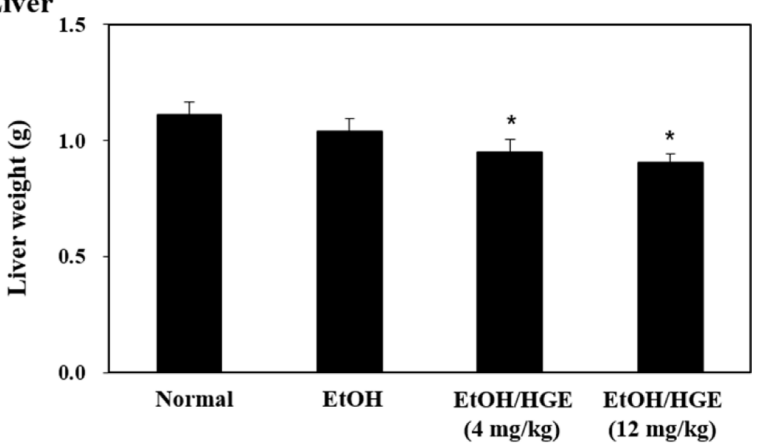

(D) Liver/Body

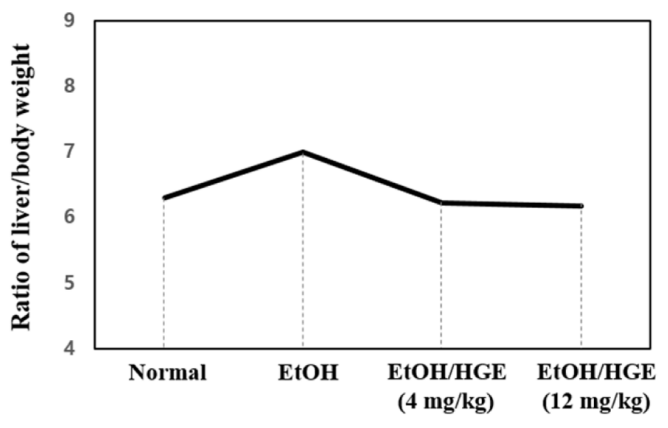

Fig. 3 Effect of HGE on tissue weight in EtOH-fed mice. Mice were administered with EtOH in the presence of absence of HGE. At the end of EtOH, the livers and spleens were isolated and weighted. Body weight was expressed as an increase percentage of animal weight. The results are expressed as means \pm SD of 7 mice. ${ }^{*} p<0.05$, compared with the EtOH-fed group

(A)

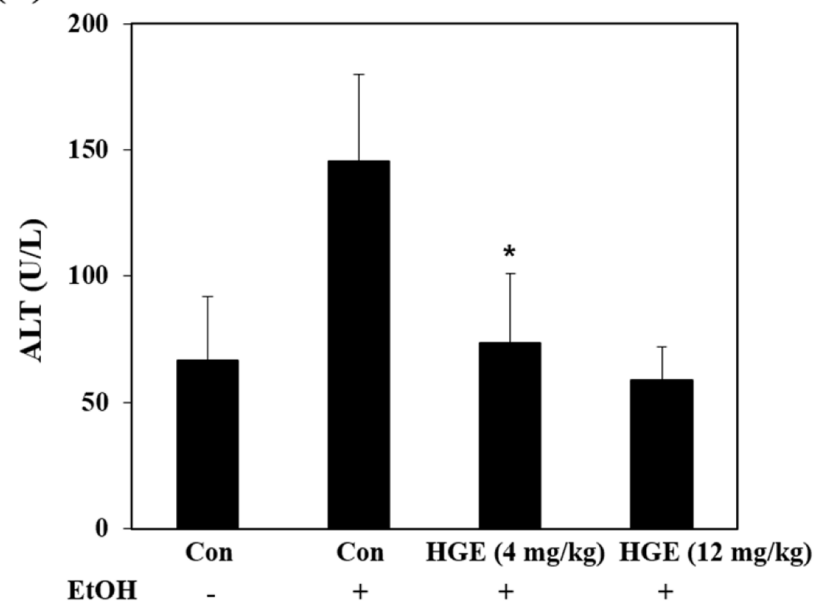

(B)

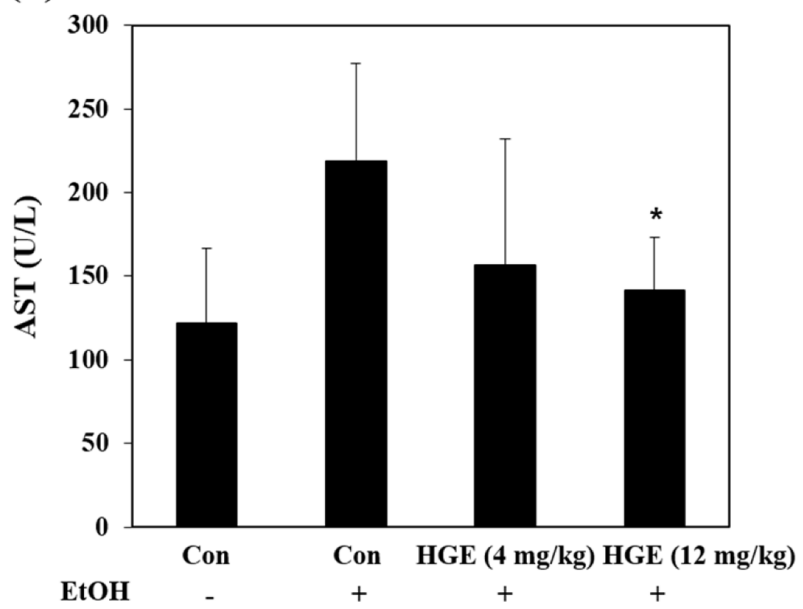

Fig. 4 Effect of HGE on the level of serum ALT and AST in AILD. The ALT (A) and AST (B) levels were measured using serum specimens collected 1 day after the final administration of EtOH. The results are expressed as means $\pm \mathrm{SD}$ of 7 mice. ${ }^{*} p<0.05$, compared with the EtOH-fed group

를 나타내어 알코올 처리를 통해 유발된 간독성이 완화되는 것

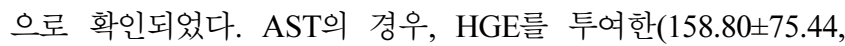
$141.60 \pm 31.33 \mathrm{U} / \mathrm{L})$ 군에서 알코올로 처리한 실험군 $(218.67 \pm 58.29$ $\mathrm{U} / \mathrm{L}$ )에 비해 농도의존적으로 낮아지는 경향을 확인하였으며, 새 싹인삼 지상부 추출물(HGE)의 간 보호 효과를 확인하였다(Fig. 4).

알코올 간독성 유발한 마우스에서 HGE 시료의 항산화 효과 Lactate dehydrogenase (LDH)는 latate와 pyruvate의 상호전환
을 가수분해하는 산화 환원 효소로써 세포막이 손상을 받으면 $\mathrm{LDH}$ 가 세포로부터 빠져나와 배양액 내 $\mathrm{LDH}$ 의 수치가 높게 나 타나게 되고 이로 인해 세포 독성을 측정하는 방법이다[32]. 알 코올성 간 독성은 기본적으로 증가된 자유 라디칼에 의해 생기 는 산화 스트레스와 항산화 시스템을 낮추는 것과 연결되어 진 다. 간 손상의 마커로써 혈중 $\mathrm{ALT}, \mathrm{AST}$, 및 $\mathrm{LDH}$ 와 같은 효소 들의 농도 증가는 간세포 손상과 세포막의 기능 손실을 나타낸 다 [33]. 따라서, 알코올성 간 손상을 준 마우스에 $\mathrm{HGE}$ 시료를 


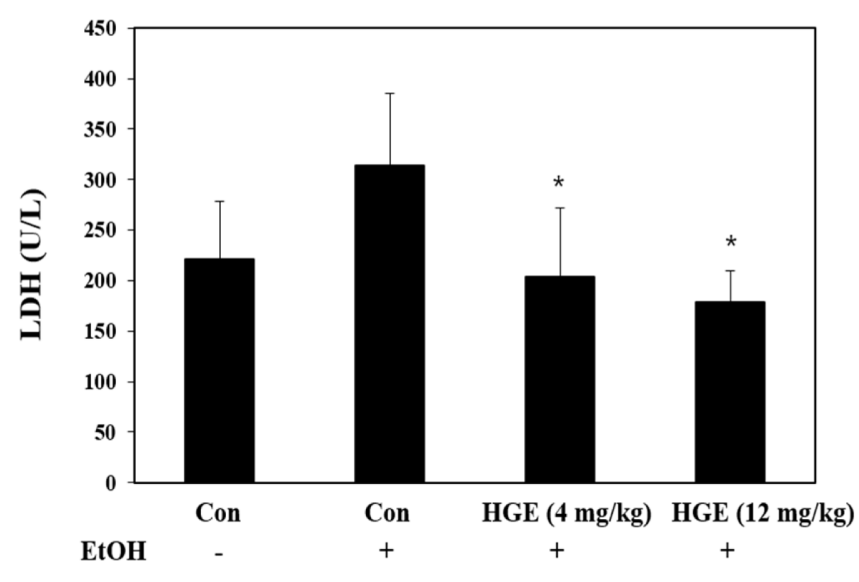

Fig. 5 Effect of HGE on the level of serum LDH in AILD. The serum LDH level was measured using serum specimens collected 1 day after the final administration of EtOH. The results are expressed as means \pm SD of 7 mice. ${ }^{*} p<0.05$, compared with the EtOH-fed group

경구투여 후, 간 지표 효소인 LDH (lactate dehydrogenase)를 조사함으로써 동물모델에서의 항산화 효과를 알아보았다. 혈중 $\mathrm{LDH}$ 의 수치는 알코올을 섭취한 군에서 증가되었고, 증가된 $\mathrm{LDH}$ 수치는 $\mathrm{HGE}$ 추출물을 4 와 $12 \mathrm{mg} / \mathrm{kg}$ 의 농도로 경구 투여 한 경우 대조군과 유사한 정도로 감소하였고, 농도가 증가할수 록 감소효과는 더 커진 것을 확인하였다(Fig. 5). 따라서, 새싹 인삼 지상부 추출물 $(\mathrm{HGE})$ 은 알코올성 간독성에 의한 산화 스 트레스를 완화시키는데 효과가 있다고 사료된다. 본 연구 결과 를 종합해 볼 때, 새싹 인삼잎 추출물이 알코올로 유발된 산화 스트레스와 간독성에 대한 보호 효과를 확인하였으며, 향후 인 체적용시험 등 추가연구를 통하여 건강기능성식품소재로 활용 될 수 있을 것으로 생각된다. 또한, 함량이 높은 ginsenoside $\mathrm{F} 2$ 는 지표성분 선정의 기초자료로 이용할 수 있을 것으로 기대 된다.

\section{초 록}

알코올성 간손상을 유발한 마우스 모델에서 새싹인삼 지상부 추 출물 $(\mathrm{HGE})$ 의 간 보호 효과를 확인하였다. 알코올성 간손상 모 델은 $25 \%$ 알코올을 마우스에 $5 \mathrm{~g} / \mathrm{kg}$ 의 농도로 경구 투여하여 이루어졌고, $\mathrm{HGE}$ 를 투여한 군에는 알코올을 투여하기 3일전부 터 경구투여를 시작하여 10 일간 마우스 개체 당 4 와 $12 \mathrm{mg} / \mathrm{kg}$ 의 농도로 경구투여 하였다. $\mathrm{HGE}$ 를 투여한 그룹에서는 알코올 만 처리한 대조군에 비해 AST 및 ALT 수치가 농도의존적으로 낮아진 것을 확인하였다. 또한, 간손상에 의해 증가된 $\mathrm{LDH}$ 수 치는 대조군과 유사하게 감소하였다. 새싹인삼 지상부 추출물로 부터 ginsenoside $\mathrm{F} 5, \mathrm{~F} 3, \mathrm{~F} 1$, 및 $\mathrm{F} 2$ 의 정량분석 결과는 각각 $2.5,4.4,1.4$, 및 $23.3 \mathrm{mg} / \mathrm{g}$ 으로 확인하였다.

Keywords 새싹인삼 지상부 · 알코올성 간손상 - 정량분석 · Ginsenoside
감사의 글 본 논문은 2019년도 정부재원(과학기술정보통신부 여성과학기 술인 R\&D 경력복귀 지원 사업: WISET 제 2019-585호)으로 한국연구재단과 한국여성과학기술인지원센터의 지원받아 이루어진 결과로 이에 감사드립니다.

\section{References}

1. Hwang JY, Ham JW, Nam SH (2004) Effect of Maesil (Prunus mume) juice on the alcohol metabo lizing enzyme activities. Korean J Food Sci Technol 36: 329-332

2. Zakhari S (2006) Overview: how is alcohol metabolized by the body? Alcohol Res Health 29: 245-254

3. Rouach H, Fataccioli V, Gentil M, French SW, Morimoto M, Nordmann R (1997) Effect of chronic ethanol feeding on lipid peroxidation and protein oxidation in relation to liver pathology. Hepatology 25: 351-355

4. Frazier TH, Stocker AM, Kershner NA, Marsano LS, McClain CJ (2011) Treatment of alcoholic liver disease. Theap Adv Gastroenterol 4: 63-81

5. Gramenzi A, Caputo F, Biselli M, Kuria F, Loggi E, Andreone P, Bernardi M (2006) Alcoholic liver diseased pathophysiological aspects and risk factors. Aliment Pharmacol Ther 24: 1151-1161

6. Rouach H, Clement M, Ofanelli MT, Janvier B, Nordmann R (1983) Hepatic lipid peroxidation and mitochondrial susceptibility to peroxidative attacks during ethanol inhalation and withdrawal. Biochem Biophys Acta 753: 439-444

7. Wheeler MD, Nakagami M, Bradford BU, Uesugi T, Mason RP, Connor HD, Dikalova A, Kadiiska M, Thurman RG (2001) Overexpression of manganese superoxide dis mutase prevents alcohol-induced liver injury in the rat. J Biol Chem 276: 36664-36672

8. Moncade C, Torres V, Varghese G, Albano E, Israel Y (1994) Ethanol derived immune species formed by radical mechanisms. Mol Pharmacol 46: 786-791

9. Simic MG (1988) Mechanisms of inhibition of free-radical processes in mutagenesis and carcinogenesis. Mutat Res 202: 377-386

10. Lu SC, Mato JM (2008) S-Adenosylmethionine in cell growth, apoptosis and liver cancer. J Gastroenterol Hepatol 23: 73-77

11. Purohit V, Gao B, Song BJ (2009) Molecular mechanisms of alcoholic fatty liver. Alcohol Clin Exp Res 33: 191-205

12. Park JH (2012) Antioxidant activities in shoots and roots of hydroponic cultured ginseng. J Appl Oriental medicine 12: 21-26

13. Lee JS, Lee GH, Choi SC, Choi HS, Hyun KY (2015) Effect of systemic inflammatory regulation of hydroponic cultured ginseng in arthritis rat. Asia-pacific Journal of Multimedia Services Convergent with Art, Humanities, and Sociology 5: 61-70

14. Lee SH, Song YS, Lee SY, Kim SY, Ko KS (2014) Protective effects of Akebia quinata fruit extract on acute alcohol-induced hepatotoxicity in mice. Korean J Food Sci Technol 5: 622-629

15. Hou YL, Tsai YH, Lin YH, Chao JC (2014) Ginseng extract and ginsenoside $\mathrm{Rb} 1$ attenuate carbon tetrachloride-induced liver fibrosis in rats. BMC Complement Altern Med 14: 415-423

16. Kim YB, Hyun DY, Kim GS, Cha SW, Song BH (2013) Effect of LED irradiation on ginsenoside contents and growth of Panax ginseng $\mathrm{C}$ A Meyer cultured by hydroponicsystem. Korean journal of horticultural science \& tecnology 31: 196

17. Siddiqi MH, Siddiqi MZ, Ahn S, Kang S, Kim YJ, Sathishkuma N (2013) Ginseng sap onins and treatment of osteoporosis. J Ginseng Res 37: $261-268$

18. Hong SH, Suk KT, Choi SH, Lee JW, Sung HT, Kim CH (2013) Antioxidant and natural killer cell activity of Korean red ginseng (Panax ginseng) and urushiol (Rhus vernicifera stokes) on non-alcoholic fatty liver disease of rat. Food Chem Toxicol 55: 586-591

19. Kim J, Kim SH, Lee DS, Lee DJ, Kim SH, Chung S, Yang HO (2013) Effects of fermented ginseng on memory impairment and $\beta$-amyloid 
reduction in Alzheimer's disease experimental models. J Ginseng Res 37: 100-107

20. Shi W, Wang Y, Li J, Zhang H, Ding L (2007) Investigation of ginsenosides in different part and ages of Panax ginseng. Food Chem 664-668

21. Choi KT (2008) Botanical characteristics, pharmacological effects and medicinal components of Korean Panax ginseng. Acta Pharmacol Sin 29: $1109-1118$

22. Dewanto V , Wu X , Adom KK , Liu RH (2002) Thermal processing enhances the nutritional value of tomatoes by increasing total antioxidant activity. J Agr Food Chem 50: 3010-3014

23. Lee YM, Bae JH, Jeong HY, Kim JH. Park DS (2011) Antioxidant activity in water and methanol extracts from korean edible wild plants. J Korean Society of Food Sci Nutr 40: 29-36

24. Shibata S, Tanaka T, Ando T, Sado M, Tsushima S, Ohsawa T (1966) Chemical studies on oriental plant drugs (XIV). Protopanaxadiol a genuine sapogenin of ginseng saponin. Chem. Pharm. Bull. 14: 595-600

25. Tung NH, Uto T, Morinaga O, Kim YH, Shoyama Y (2012) Pharmacological effects of ginseng on liver functions and diseases: A minireview. Evid Based Complement Alternat Med doi: 10.1155/2012/ 173297

26. Jeong SJ, Kim KH (2015) Whitening and antioxidant activities of solvent extracts from hot-air dried Allium hookeri. J Korean Soc Food Sci Nutr 44: 832-839

27. Jang AY, Sueng YC, Ji JG (2016) The comparative study on physiological activity of white ginseng, red ginseng and black ginseng extract. Journal of digital convergence. 14: 459-471

28. Han DS, Kim SJ (1994) SOD-like compounds and development of functional food. Bulleutin of Food Technology 7: 41-49

29. Umulis DM, Gurmen NM, Singh P, Fogler HS (2005) A physiologically based model for ethanol and acetaldehyde metabolism in human beings. Alcohol 35: 3-12

30. Lee SH, Song YS, Lee SY, Kim SY, Ko KS (2014) Protective effects of Akebia quinata fruit extract on acute alcohol-induced hepatotoxicity in mice. Korean J Food Sci Technol 5: 622-629

31. Tundis R, Loizzo MR, Menichini F, Statti GA, Menichini F (2008) Biological and pharmacological activities of iridoids: recent developments. Mini Rev Med Chem 8(4): 399-420

32. Koh JY, Choi DW (1987) Quantitative determination of glutamate mediated cortical neuronal injury in cell culture by latate dehydrogenase efflux assay. J Neurosci Meth 20: 83-90

33. Tundis R, Loizzo MR, Menichini F, Statti GA, Menichini F (2008) Biological and pharmacological activities of iridoids: recent developments. Mini Rev Med Chem 8(4): 399-420 